POLICY BRIEFING SERIES

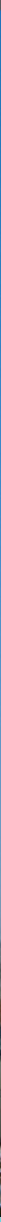

\title{
From Karlsruhe, with Love? \\ Questioning the Constitutionality of Unconventional Monetary Policy
}

Dr Michael Wilkinson 


\section{From Karlsruhe, with Love? Questioning the Constitutionality of Unconventional Monetary Policy}

Does the European Central Bank (ECB) have a mandate to do 'whatever it takes' to save the Euro? Not according to the German Constitutional Court, which in February this year delivered its judgment from Karlsruhe on the ECB's Outright Monetary Transactions programme (OMT). Will the European Court of Justice concur, or will it attempt to resist the might of the most powerful domestic Court in Europe?

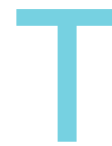

hrough the OMT programme, the ECB had promised unlimited purchases on secondary markets of bonds from selected member states, signalling that it would act in effect as the Eurozone's 'lender of last resort'. Although not triggered in practice, the availability of OMT apparently stabilised the Euro area, calming financial markets and reducing 'irrationally' high spreads on the sovereign bonds of ailing states.

In its decision, the German Constitutional Court strongly doubted the legality of the ECB's bond-buying programme. As an act of economic policy, it manifestly violates the distribution of power between the EU and its Member States (see paras 63-69) and probably amounts to central bank financing of the state, prohibited by Article 123(1) TFEU (see paras 84-94). But rather than attempt to revoke the license immediately, the German Court, making good on an earlier promise, made its first ever reference to Luxembourg, giving the European Court of Justice an opportunity to review the programme before rendering a final assessment. A judgment from the European Court is expected in the summer of 2015

Whether or not OMT was the 'big bazooka' that was called for to rescue the single currency, it was more than merely a water pistol, even if launched inconspicuously by the ECB in the form of a press release. The German court's challenge to the ECB's competence to pursue the programme raises a number of questions. If the ECB has no license for this type of weapon, will the survival of the Eurozone be jeopardised? And if, as Chancellor Merkel has insisted, the survival of the Euro determines the fate of Europe, is the future of European integration itself called into question?

In terms of its economic implications, the significance of Karlsruhe's judgment appears, so far at least, to have been slight. The OMT, properly licensed or not, may have already served its purpose, successfully lowering spreads on ailing member states.
And yet for the ECJ the stakes remain high. Economically, the Eurozone is still fragile, even, on some accounts, facing a period of 'secular stagnation'. Although the financial markets seemed untouched by Karlsruhe's initial bark, Luxembourg's bite could be a wholly different matter.

The German Court has provided the outlines of a barely lit escape route for the ECJ. If the OMT is limited in amounts, avoids any debt cuts and does not interfere with market price, then revocation of its licence may be unnecessary. But to the extent that these conditions are testable in any meaningful sense they would, arguably, make the weapon entirely ineffective, and risk deepening and prolonging the economic crisis in Europe.

\section{Moral Hazard}

Economic and Monetary Union (EMU) was set up so that the EU would have exclusive competence on matters of monetary policy, with its Central Bank setting short-term interest rates for the euro area with the primary goal of maintaining 'price stability' (Article 127(1) TFEU). The Member States, subject only to soft-law methods of 'co-ordination' among them, would retain primary economic self-determination, setting their own policies on how to tax and spend.

The ability of Member States to borrow - and so to service their existing debts would be determined by market forces, prompting them to maintain budgetary discipline, and whatever else matters for credit rating agencies. Hence the 'no bail-out' provision in Article 125(1) TFEU, which formally seeks to avoid the problem of 'moral hazard': namely the danger that with the availability of financial support from elsewhere, states would be de-incentivised from keeping strict fiscal discipline and investors from properly calculating the risk of their investments. With national fiscal liability would come national fiscal responsibility, supposedly disciplined by the markets and buttressed constitutionally (albeit weakly) by the stability and growth pact, which was violated almost immediately by France and Germany and under-enforced by the European institutions.

The basic framework of EMU has significantly mutated as a result of postcrisis reforms, including the twin pillars of the European Stability Mechanism (ESM) and the Fiscal Compact (TSCG), which provide conditional financial assistance to beleaguered Member States and heightened supervision over national budgets respectively.

The legal support for these mutations has so far held together, if only just. In Pringle, the ECJ rationalised the legality of the ESM by positing a higher goal of 'financial stability of the euro area as a whole' (rather than merely 'price stability'). And the strict conditionality ('austerity') imposed on ESM recipient states through the Memoranda of Understanding negotiated with the 'Troika' would mitigate any disincentive for fiscal discipline that might otherwise arise from new funding arrangements.

But this support is now seriously threatened. OMT might be a step too far, jeopardising the strict conditionality imposed on debtor states via ESM and undermining the principles of budgetary discipline and market rationality sacrosanct for Germany. And Karlsruhe has no truck with the notion that markets were pricing Greek debt irrationally due to an unfounded fear of reversibility of the euro in the aftermath of the financial crisis. Here it defers to the scientific expertise of its own Bundesbank. Greece, on this view, was paying for its profligacy, not for the absence of panEuropean solidarity.

The notion that any higher-level goal of financial stability of the euro area as a whole could empower the European Central Bank is rejected by the German Court. The argument that resonated is clear: 'the ECB does not have a mandate to defend the Euro by any means'. Avoidance of moral hazard and its market logic are in danger of being elevated to the status of inviolable constitutional norms in Europe. The full cost of this to the project of integration remains to be seen.

\section{Constitutional Hazard}

But does Karlsruhe's first ever reference to the ECJ reveal another kind of hazard? Although feted by some as an act of judicial comity, it has been described, more accurately, as a 'diktat', presenting the ECJ with an unhappy choice between three unpalatable options: invalidate the OMT programme; render it ineffective (by adopting the escape route offered to it); or risk constitutional collision with Germany. 
In some respects, this confrontation has been a while coming. It has long been a refrain in European legal scholarship that the German court has put up strong, if ultimately untested, resistance to the authority of EU law, based on concerns first of human rights, and then of democratic legitimacy.

In this latest round of shadow-boxing, however, Karlsruhe is packing an extra punch: 'constitutional identity'. In its view, not only is the act of the ECB manifestly ultra vires, it also violates core constitutional identity, specifically the right to vote in the Bundestag, indirectly protected via the principle of democracy by the 'Eternity Clause', article 79(3) GG (paras 26-30, 37). Germany's democratic sovereignty in fiscal matters, in the Court's view, would be jeopardised if it has to pay, however indirectly, for the $E C B$ 's indiscretion. The unconventional economics of OMT is therefore caught between the rock of ultra vires and the hard place of unconstitutionality.

The German Court's decision is especially difficult for the ECJ because it blurs the boundaries between the two legal orders, national and European. According to EU law, the ECJ has exclusive competence to rule on the validity of EU acts, such as OMT. It does so on the basis of EU and not national law, including now in accordance with the duty to respect national identity in Article 4 (2) TEU. But separating EU law from German constitutional law is far from straightforward in this case because the question whether the act is a 'manifest and structurally significant transgression' for the purposes of ultra vires seems to depend not only upon its effects in the EU legal order but also on the constitutional identity of Germany (see para 37).

This means that even if the ECJ interprets the OMT programme in a manner compatible with EU law (though in a manner distinct from that offered by the German Court) it could still fall foul of German constitutional exceptionalism and the German Court could order its national authorities, including the Bundesbank, to frustrate its implementation. Thus Karlsruhe is able to use its leverage to place enormous pressure on the ECJ to follow its own judgment of the situation. This time the dog has 'bitten' and not merely 'barked'.

If it was part of the genius of the German court to present its view on European integration as a forceful synthesis of national and European constitutional values, prodding and probing the EU to be more responsive to its concerns about the legitimacy of the European construct, there was little doubt that these concerns were genuine, even though aired from a German point of view. And therein lies the rub.

Some sort of balance must surely be sought between the values of European community on the one hand and of national autonomy on the other. But it is doubtful that this can be achieved by national high courts declaring 'unilateral opt-outs from European law' when the interests of other member states and the EU 'have no voice at all'. As Fritz Scharpf has argued, Karlsruhe's jurisprudence 'appears fundamentally flawed because the court has failed to consider its generalized implications in the light of the Kantian categorical imperative.' Karlsruhe fails, in other words, a version of the golden rule of ethics.

This raises the prospect of what I call 'constitutional hazard', the risk that the European construct will be determined by the constitutional power of a domestic court with disproportionate influence.

Since the financial crisis, increasing imbalances in the structure of the EU have threatened the principle of political equality of Member States, with fears of a 'German Europe' now being openly articulated. The OMT decision reveals a factor aggravating these imbalances, 'constitutional power', where the influence of a national constitutional court in an asymmetric compound polity such as the EU is a feature not of its legal authority but its political clout.

Constitutional hazard is not reducible entirely to the fashionable notion of German hegemony but must take into account the historical particularities of of its domestic constitutional settlement. But it is deeply ironic that rules of the game entrenched to avoid a return to dictatorship now empower the German hegemon in the world of European constitutional politics, pushing and prodding the European institutions as well as provide a missing channel for Germans to voice their Euro-scepticism.

\section{Economic Messianism}

Whatever the ECJ's response, the German judicial challenge to OMT reveals a fundamental weakness at the heart of the EU's political constitution. As a result of the structure of economic and monetary union, the Euro is a 'currency without a state', lacking the bonds of statehood to guarantee its viability. And yet it is deemed integral to the success of the project of integration, so much so that, in times of crisis, unconventional measures are effected for its rescue. The Euro has become a latter-day emblem of what might be called 'economic Messianism', displacing the 'political Messianism' of the founding fathers of European Union. The Euro is apparently key to the survival of the EU, but a monetary project is a poor substitute for a community of solidarity that normally undergirds the fate of a polity.

It may be that for the German court, such matters are to be dismissed as irrelevant and irrational. And yet they cannot be ignored; to do so would be to yield totally to a partial economic worldview, which replaces political action and the values of European constitutionality with scientific expertise (of the Bundesbank) and market logic. What is at stake is not, ultimately, the defence of a domestic Rechtsstaat against a European raison d'État. After all, the German Constitutional Court is also defending a substantive political and economic view, one which values price stability, competitiveness, and fiscal discipline above all else.

The OMT judgment illuminates the special responsibility of the judicial role in Europe, with national and European courts having to balance issues of complex equality of persons and of states in a context of increasing economic and political imbalances between nations. The ECJ has its work cut out.

It seems unlikely that the ECJ would risk direct confrontation with Karlsruhe. But if, for the German court the logic of European integration remains primarily based on imperatives of competitiveness and market logic, for the ECJ, this can present but one facet of the broader European constitutional logic against which OMT must be judged. This more expansive evaluation must include not only imperatives of competitiveness and market logic, but also of peace, prosperity, and solidarity between peoples. The OMT may fail a more holistic test too, but only in posing it in its full constitutional context, can a Court properly discharge its duty.

Dr Michael Wilkinson (Department of Law, London School of Economics and Political Science) 


\section{MIKE WILKINSON}

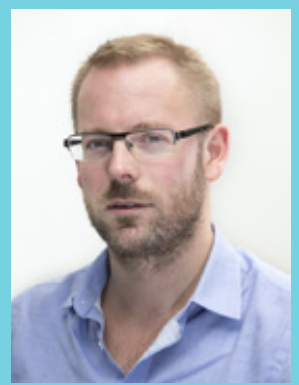

Mike Wilkinson is Associate Professor of Law at LSE, working on questions of European integration and constitutional theory. Prior to taking up his post at LSE in September 2007, Mike was lecturer at Manchester University, EU-US Fulbright Research Fellow at Columbia and NYU and was called to the Bar (Lincoln's Inn) in 2000.

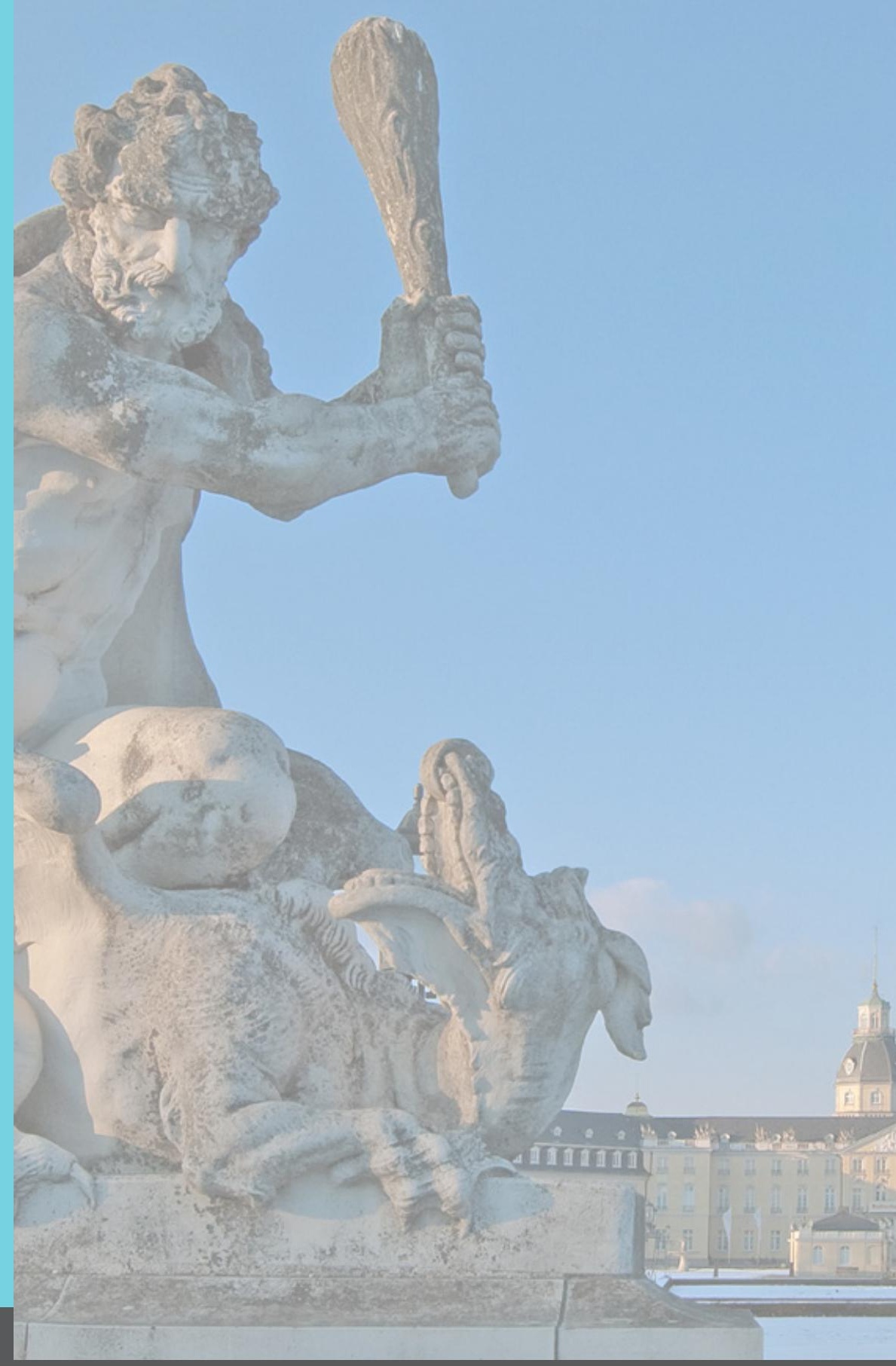

THE LONDON SCHOOL

OF ECONOMICS AND POLITICAL SCIENCE

Department of Law

The London School of Economics

and Political Science

Houghton Street

London WC2A 2AE 